\title{
Symphyotrichum subulatum (Michx.) G.L.Nesom (Asteraceae): a new distribution record of an alien plant species in Kashmir Himalaya, India
}

\author{
Ruquia Gulzar ${ }^{1}$, Anzar A. Khuroo ${ }^{1 *}$, Zubair A. Rather ${ }^{1}$, Rameez Ahmad ${ }^{1}$, Irfan Rashid ${ }^{2}$ \\ 1 Centre for Biodiversity and Taxonomy, Department of Botany, University of Kashmir, Srinagar, Jammu and Kashmir, India \\ • RG: mirruquia1@gmail.com (D https://orcid.org/0000-0002-7970-3512 • AAK: anzarak@gmail.com (1) https://orcid.org/0000-0002-0251- \\ 2793 •ZAR: zubairrather4@gmail.com (1) https://orcid.org/0000-0001-6924-2321 •RA: rameezkhuroo929@gmail.com (1) https://orcid.org/ \\ 0000-0002-4229-986X \\ 2 Department of Geoinformatics, University of Kashmir, Srinagar, Jammu and Kashmir, India • IR: irfangis@gmail.com (® https://orcid.org/0000- \\ 0002-5214-1919 \\ * Corresponding author
}

\begin{abstract}
Symphyotrichum subulatum (Michx.) G.L.Nesom (Asteraceae) is reported as a new alien plant record for Kashmir Himalaya. The taxonomic identification of species is confirmed on the basis of shape of involucre, floral and seed characters. Detailed description, distribution map, and comments on distribution and ecology are also provided along with photographic illustration to facilitate easy identification of this species.
\end{abstract}

\section{Keywords}

Alien species, biodiversity, diagnostic characters, Himalaya, taxonomy

Academic editor: Arjun Prasad Tiwari | Received 28 November 2020 | Accepted 15 March 2021 Published 30 March 2021

Citation: Gulzar R, Khuroo AA, Rather ZA, Ahmad R, Rashid I (2021) Symphyotrichum subulatum (Michx.) G.L.Nesom (Asteraceae): a new distribution record of an alien plant species in Kashmir Himalaya, India. Check List 17 (2): 569-574. https://doi.org/10.15560/17.2.569

\section{Introduction}

Asteraceae, one of the largest families of angiosperms, is currently represented by 32,872 species globally (CWG 2020). The members of this family are easily recognized by their characteristic capitulum (head) inflorescence, which usually comprises of ray and disc florets. The Asteraceae exhibit great variability in characters such as the number and association of stamens, shape and type of anther, stigma, and pappus, and form, size, and morphology of achenes (Funk et al. 2009). In Asteraceae, the genus Symphyotrichum Nees comprises approximately 100 species, which are mainly distributed across the
New World (Tunckol et al. 2017). Symphyotrichum taxa are mostly annual or perennial herbs, with stem erect or ascending, leaves of two types (basal and cauline), involucre cylindrical, hemispheric, or campanulate, phyllaries in 2-5 series, ray florets in 1-5 series, disc florets bisexual and funnel-shaped, and achenes lanceoloid to obovoid.

Only one species of Symphyotrichum, S. subulatum (Michx.) G.L.Nesom, has been reported in India, from the tropical to subtropical areas of the Gangetic Plains biogeographical zone (Sharma et al. 2012), and from 
Uttar Pradesh by its synonym, S. squamatum (Spreng.) G.L.Nesom (Tripathi and Sharma 2019; Fig. 1). From Kashmir Himalaya, a temperate mountainous region located at the northwestern edge of the Himalayas biogeographical zone, another species, Symphyotrichum pilosum (Willd.) G.L.Nesom, has been recorded, but its occurrence there is doubtful, as there has been no subsequent authentic record in that region and no voucher specimen is available (Kaul 1975). During recent botanical surveys, we collected specimens of a naturally occurring Symphyotrichum species which we found in abundant populations from various localities in Kashmir Himalaya. On detailed study of the diagnostic features of collected fresh plant material, and a review of the taxonomic literature (Nesom 2005; Sharma et al. 2012), we identified the species as Symphyotrichum subulatum, which is a newly recorded alien plant species in Kashmir Himalaya (Fig. 1). The species is actually native of New World with distribution range from eastern Canada to Mexico and the Caribbean (POWO 2019).

We document the new records of $S$. subulatum in Kashmir Himalaya and provide a detailed taxonomic description based on the voucher specimens collected from this Himalayan region. Microphotographs of diagnostic characters of $S$. subulatum are included, which will facilitate its identification in the field.

\section{Methods}

Our study was conducted in Kashmir Himalaya, which has an area of approximately $15,000 \mathrm{~km}^{2}$ with $64 \%$ of it mountainous (Fig. 1). The climate is primarily continental and temperate, with cold, wet winters and relatively dry, hot summers (Rashid et al. 2019, 2020). The region's temperature ranges from an average daily maximum of $31{ }^{\circ} \mathrm{C}$ and minimum of $15{ }^{\circ} \mathrm{C}$ during summer to an average daily maximum of $4{ }^{\circ} \mathrm{C}$ and minimum of $-4{ }^{\circ} \mathrm{C}$ during winter. The average annual precipitation is $1055 \mathrm{~mm}$, mostly in the form of snow. The region's natural vegetation mostly consists of alpine meadows and coniferous forests (Dar and Khuroo 2013).

During floristic surveys, standard taxonomic methods have been followed for the collection, drying, and processing of herbarium specimens (Bridson and Forman 1998). The specimens have been deposited in University of Kashmir Herbarium (KASH). To identify the species, we consulted relevant taxonomic literature (Nesom 2005; Sharma et.al 2012), online floras (Flora of China 2008; POWO 2019; eFlora of India 2020; Jepson Flora 2020). The field photographs were taken using a Xiaomi Redmi Note7 mobile phone camera. The microphotography of the diagnostic characters was carried out under a Leica S9D stereozoom microscope integrated with LAS X image processing software.

\section{Results}

\section{Symphyotrichum subulatum (Michx.) G.L.Nesom \\ Annual Saltmarsh Aster \\ Figures 2, 3}

Global distribution. Native to North America and South America; introduced into Europe, Africa, Australasia, Asia temperate and Pacific (GRIN 2020)

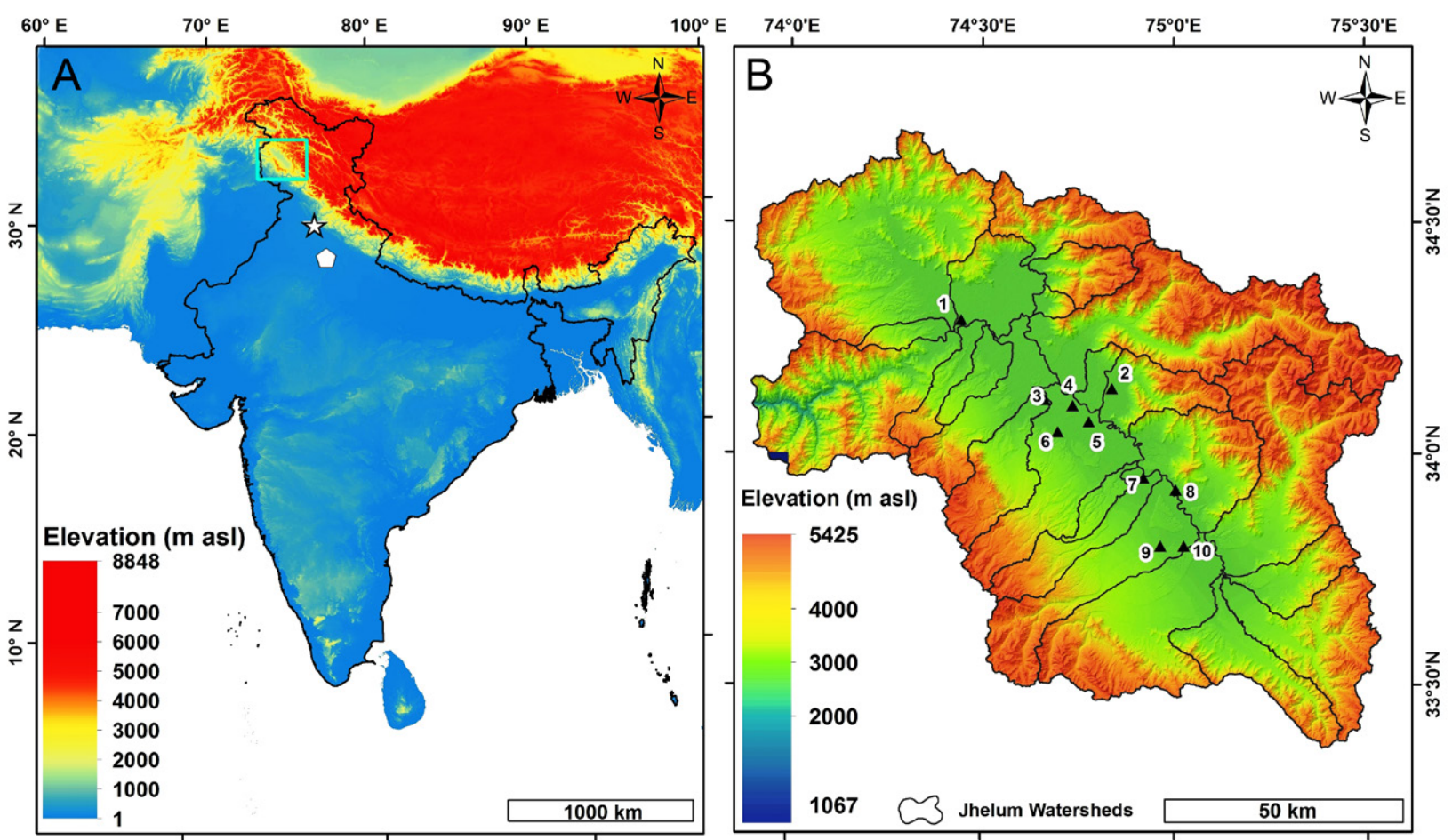

Figure 1. Distribution map of Symphyotrichum subulatum in Kashmir Himalaya. A. Previous records in mainland India. Star = Patiala (Punjab) and pentagon = Noida (Uttar Pradesh). Cyan rectangle represents Kashmir Himalaya. B. New occurrence records across the Kashmir Himalaya (triangles 1-10). 

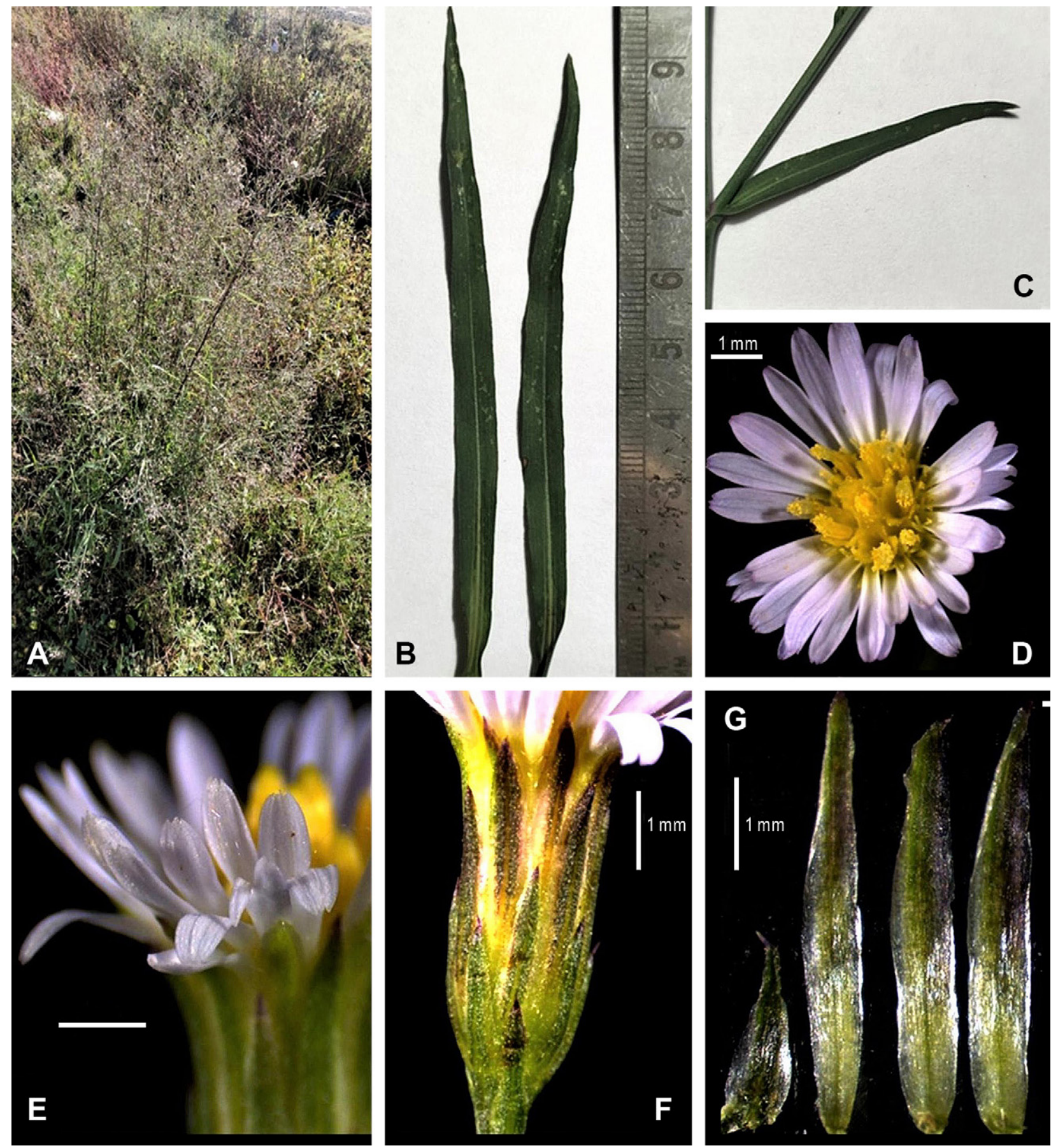

Figure 2. Symphyotrichum subulatum. A. Habit. B. Leaves. C. Axillary branch. D. Inflorescence head with ray and disc florets. E. Two- to three-seriate ray florets. F. Cylindrical lateral view of head with four-seriate phyllaries, purplish tipped. G. Phyllaries from basal (left) to upper (right) series.

Materials examined. INDIA • Jammu and Kashmir, Sopore Baramulla; 341'1'N, 074²6'46" E; $1594 \mathrm{~m}$ a.s.1.; 21 Sep. 2020; R. Gulzar, A.A. Khuroo leg.; KASH 45035 - Hazratbal Srinagar; $34^{\circ} 08^{\prime} 28^{\prime \prime} \mathrm{N}, 074^{\circ} 50^{\prime} 20^{\prime \prime} \mathrm{E}$; 1600 m a.s.1.; 10 Sep. 2020; R. Gulzar, A.A. Khuroo leg.; KASH 45036 - Tengpora Srinagar; $34^{\circ} 04^{\prime} 11^{\prime \prime} \mathrm{N}, 074^{\circ}$ 46'46"E; 1610 m a.s.1.; 6 Oct. 2020; R. Gulzar, Z.A. Rather leg.; KASH 45037 • Narbal Budgam; 3407'02"N, 074³9'51"E; 1591 m a.s.1.; 7 Oct. 2020; R. Gulzar, Z.A. Rather leg.; KASH 45041• HMT Srinagar; 3406'16"N, 074'44'14"E; $1574 \mathrm{~m}$ a.s.1. ;7 Oct. 2020; R. Gulzar, A.A.Khuroo leg.; KASH 45040 • Kakapora Pulwama;

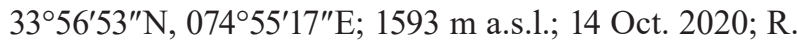
Gulzar, A.A. Khuroo leg.; KASH 45043 - Awantipora Pulwama; $33^{\circ} 55^{\prime} 19^{\prime \prime} \mathrm{N}, 075^{\circ} 01^{\prime} 18^{\prime \prime} \mathrm{E}$; $1591 \mathrm{~m}$ a.s.l.; 14 Oct. 2020; R. Gulzar, A.A. Khuroo leg.; KASH 45042 - Kachkoot Pulwama; 3348'01"N, 07457'55"E; 1594 m a.s.1.; 14 Oct. 2020; R. Gulzar, A.A. Khuroo leg.; KASH 45039 - Nasrullahpora Budgam; 3402'51"N, 07441' 58"E; 1626 m a.s.l.; 18 Sep. 2020; R. Gulzar, A.A. Khu-

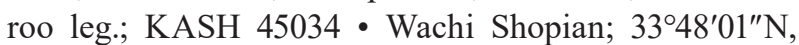
07501'35"E; 1598 m a.s.1.; 30 Sep. 2020; R. Gulzar, A.A. Khuroo leg.; KASH 45038.

Identification. Annual herb, 16-200 cm tall. Stem erect, 


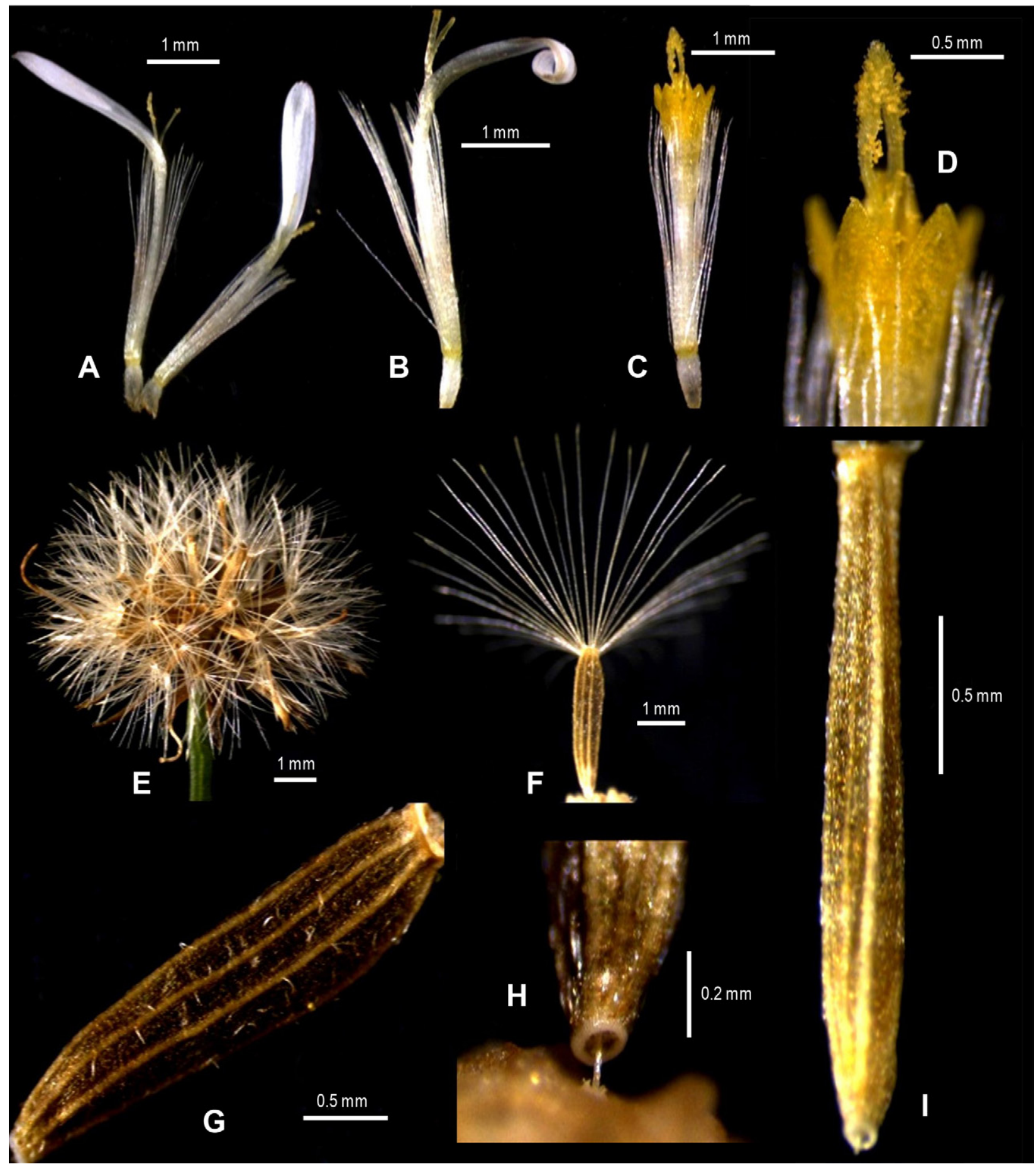

Figure 3. Flower and fruit characters of Symphyotrichum subulatum. A. Ray floret with bifid stigma. B. Curling of petal in ray floret. C. disc floret. D. Feathery, bifid, and spoon-shaped stigma in disc floret. E. Inflorescence head with cypsela fruits. F. Cypsela with pappus. G. Dorsal view of cypsela with ridges and furrows. H. Attachment of cypsela with receptacle. I. Lateral view of cypsela.

branched, glabrous, green, becomes purplish on maturity. Leaves of two types: basal leaves petiolate, lanceolate to ovate, wither at anthesis; cauline leaves sessile, linear to lanceolate, $2-14 \times 0.1-1.0 \mathrm{~cm}$, becoming smaller in size upwards, adaxial and abaxial leaf surfaces glabrous, base attenuate, margin serrulate to entire, apex acute. Inflorescence capitula in paniculiform synflorescences. Involucre cylindrical, phyllaries 3- or 4 seriate, lanceolate, clearly unequal, $2-6 \times 0.2-0.5 \mathrm{~mm}$, margin entire, tip acute and prominently purplish. Ray florets 2- or 3 seriate, 34-36 in number, 6-7 mm long, lamina bluish or pinkish white, coiling backwards; stigma bifid; bristles whitish, 3-4 mm long. Disc florets 12-14 in number, yellow, 5-6 $\mathrm{mm}$ long; lobes erect and triangular; stigma feathery and spoon-shaped. Fruit cypsela (achene), lanceoloid, $2.5 \times 0.6 \mathrm{~mm}, 6$-veined, strigillose. Pappus bristly, white, 3-4 mm long. (Figs. 2A-G, 3A-I).

Phenology. Flowering and fruiting from August to November.

Habitat. Growing along paddy fields and roadsides and at riparian sites. 
Associated species. Cynodon dactylon (L.) Pers., Trifolium pratense L., Poa annua L., Echinochloa crus-galli L., Erigeron canadensis L., Setaria viridis (L.) P.Beauv., Persicaria hydropiper (L.) Delarbre, Plantago major L., Cichorium intybus L., Bromus catharticus Vahl, Cirsium arvense (L.) Scop., and Taraxacum officinale Anon.

Invasion status. Based on our field studies, S. subultatum may be potentially invasive (sensu Pysek et al. 2004) in Kashmir Himalaya. This species is capable of producing a large number of viable seeds ranging from 500 to 50,000 per individual (Fig. 3) and has spread from Sopore in the north to Shopian in the south of Kashmir Himalaya, which cover more than $100 \mathrm{~km}$ (Fig. 1).

\section{Discussion}

Of the various shortfalls in biodiversity knowledge, the Wallacean shortfall refers to lack of distributional data (Hortal et al. 2015). To fill the Wallacean shortfall, new distribution data for plants and animals from around the world (Rasheed et al. 2015; Arshid et al 2016; Rather et al. 2019) and in particular the data-deficient biodiversity hotspots in the developing world, such as the Himalaya, are an urgent research priority. Also, biological invasions by alien species have emerged in recent times as one of the main drivers of global biodiversity loss (Khuroo et al. 2011; Thapa et al. 2018). Thus, identifying and recording the alien species which have the potential to become invasive is crucial in developing well-informed invasion management strategies (Khuroo et al. 2012). Kashmir Himalaya is situated on the north-western side of the Himalaya, a globally significant biodiversity hotspot (Zachos et al. 2011). The region is well known for its rich biodiversity with a large proportion of endemic species (Dar and Khuroo 2020). The region possesses an estimated 3000 plant species (Dar and Khuroo 2013). In fact, new additions to the flora of Kashmir Himalaya are continuously reported (Ganie et al. 2014; Rasheed et al. 2015; Muzafar et al. 2016; Hassan et al. 2020).

With reportedly rapid climate change in the Himalaya, it is important to document distributional and altitudinal changes in the distribution of species (Hamid et al. 2018; 2020). In various parts of Kashmir Himalaya, alien species which have been established for many years are common in orchards, parks, crop fields, and gardens, as well as along roadsides. In Kashmir Himalaya, as many as 54 alien species of Asteraceae have been reported, and some of these have become naturalized and displace the native vegetation (Khuroo et al. 2007). Some of these alien species have become invasive and have negative effects on the growth and propagation of native biodiversity (Ahmad et al. 2019a; 2019b). In this context, we record for the first time $S$. subulatum as an alien plant in the Kashmir Himalaya, India. Our data on this species in the Himalayan region may help in predicting the future spread of this potentially invasive species and initiating actions for its management and control.

\section{Acknowledgements}

We thank research students: Maroof, Tabasum, Aadil, Bilal, Firdoos, and Tajamul at the Centre for Biodiversity and Taxonomy, Department of Botany, University of Kashmir, for their kind help. Ruquia Gulzar acknowledges financial support received as a Junior Research Fellow from the Council of Scientific and Industrial Research (India) during this study. Two anonymous reviewers and the academic editor, Arjun Prasad Tiwari, are acknowledged for their useful comments, and Robert Forsyth for language editing, which improved the manuscript.

\section{Author Contributions}

AAK conceived the study; RG, AAK, ZAR, and RA collected the field data; AAK and RG identified the specimens; RG and ZAR carried out photography; IR prepared the distribution map; RG wrote the first draft of the manuscript with input from AAK and IR; all the authors reviewed the draft manuscript and agreed to its submission.

\section{References}

Ahmad R, Khuroo AA, Hamid M, Malik AH, Rashid I (2019a) Scale and season determine the magnitude of invasion impacts on plant communities. Flora 260: 151481. https://doi.org/10.1016/j. flora.2019.151481

Ahmad R, Khuroo AA., Hamid M, Rashid I (2019b) Plant invasion alters the physico-chemical dynamics of soil system: insights from invasive Leucanthemum vulgare in Indian Himalaya. Environmental Monitoring and Assessment 191: 792. https://doi. org/10.1007/s10661-019-7683-X

Arshid S, Wani AA, Ganie AH, Khuroo AA (2016) On correct identification, range expansion and management implications of Myriophyllum aquaticum in Kashmir Himalaya, India. Check List 7 (3): 299-302. https://doi.org/10.15560/7.3.299

Bridson D, Forman L (1998) The herbarium handbook. Royal Botanic Gardens, Kew, UK, 291 pp.

CWG (Compositae Working Group) (2020) Global Compositae database. http://www.compositae.org. Accessed on: 2020-9-25. https:// doi.org/10.14284/411

Dar GH, Khuroo AA (2013) Floristic diversity in the Kashmir Himalaya: progress, problems and prospects. Sains Malaysiana 42 (10): 1377-1386.

Dar GH, Khuroo AA (2020) (Eds.) Biodiversity of the Himalaya: Jammu and Kashmir state (Vol. 18). Springer Nature, Singapore, $1096 \mathrm{pp}$.

eFlora of India BSI (2020) Database of Indian plants: developed by the members of eFlora of India Google group. https://sites.google. com/site/efloraofindia/. Accessed on: 2020-10-3.

Flora of China (2008) http://www.efloras.org/. Accessed on: 30-092020.

Funk VA, Susanna A, Steussy TF, Robinson H (2009) Classification of Compositae. In: Funk VA, Susanna A, Stuessy TF, Bayer RJ (Eds.) Systematics, evolution, and biogeography of Compositae. International Association for Plant Taxonomy, Vienna, Austria, 171-189.

Ganie AH, Tali BA, Khuroo AA, Nawchoo IA, Rather AM (2014) Rheum spiciforme Royle (Polygonaceae): a new record to the flora of Kashmir Valley, India. National Academy Science Letters 37 (6): 561-565. https://doi.org/10.1007/s40009-014-0279-7 
GRIN (Germplasm Resources Information Network) (2020) http:// www.arsgrin.gov/cgi-bin/npgs/html/index.pl. Accessed on: 2020 $10-2$.

Hamid M, Khuroo AA, Charles B, Ahmad R, Singh CP, Aravind NA (2019). Impact of climate change on the distribution range and niche dynamics of Himalayan birch, a typical treeline species in Himalayas. Biodiversity and Conservation 28 (8): 2345-2370. https://doi.org/10.1007/s10531-018-1641-8

Hamid M, Khuroo AA, Malik AH, Ahmad R, Singh CP (2020) Assessment of alpine summit flora in Kashmir Himalaya and its implications for long-term monitoring of climate change impacts. Journal of Mountain Science 17: 1974-1988. https://doi.org/10.1007/ s11629-019-5924-7

Hassan A, Rasheed S, Khuroo AA, Masoodi A, Nawchoo IR (2020) Nymphaea alba var rubra Lönnr. (Nymphaeaceae): a new record for the aquatic flora of Kashmir Himalaya, India. Check List 16 (4): 841-845. https://doi.org/10.15560/16.4.841

Hortal J, Bello FD, Diniz-Filho JAF, Lewinsohn TM, Lobo JM, Ladle RJ (2015) Seven shortfalls that beset large-scale knowledge of biodiversity. Annual Review of Ecology, Evolution, and Systematics 46: 523-549. https://doi.org/10.1146/annurev-ecol sys-112414-054400

Jepson Flora Project (Eds.) (2020) Jepson eFlora. https://ucjeps. berkeley.edu/eflora/. Accessed on: 2020-9-30.

Kaul MK (1975) New plant records for India from Kashmir II. Journal of the Bombay Natural History Society 72: 609-612.

Khuroo AA, Rashid I, Reshi Z, Dar GH, Wafai BA (2007) The alien flora of Kashmir Himalaya. Biological Invasions 9 (3): 269-292. https://doi.org/10.1007/s10530-006-9032-6

Khuroo AA, Reshi ZA, Malik AH, Weber E, Rashid I, Dar GH (2012) Alien flora of India: taxonomic composition, invasion status and biogeographic affiliations. Biological Invasions 14 (1): 99-113. https://doi.org/10.1007/s10530-011-9981-2

Khuroo AA, Reshi, ZA, Rashid I, Dar GH (2011) Towards an integrated research framework and policy agenda on biological invasions in the developing world: a case-study of India. Environmental Research 111 (7): 999-1006. https://doi.org/10.1016/j. envres.2011.02.011

Muzafar I, Hamid M, Khuroo A, Mehraj G, Rashid I (2016) Bromus catharticus Vahl (Poaceae): a new plant record for Kashmir Himalaya, India. Check List 12 (2): 1875. https://doi.org/10. $15560 / 12.2 .1875$

Nesom GL (2005) Taxonomy of the Symphyotrichum (Aster) subula- tum group and Symphyotrichum (Aster) tenuifolium (Asteraceae: Astereae). SIDA, Contributions to Botany 21: 2125-2140.

POWO (2019) Plants of the world online. Royal Botanic Gardens, Kew http://www.plantsoftheworldonline.org/. Accessed on: 2020-10-1.

Pysek P, Richardson DM, Rejmanek M, Webster GL, Williamson M, Kirschner J (2004) Alien plants in checklists and floras: towards better communication between taxonomists and ecologists. Taxon 53 (1): 131-143.

Rasheed S, Khuroo AA, Hamid M, Ganie AH, Malik AH, Dar GH (2015) Phalaris canariensis L. (Poaceae): a new alien plant record for Kashmir Himalaya, India. Journal of Asia-Pacific Biodiversity 9: 94-96. https://doi.org/10.1016/j.japb.2015.11.001

Rashid I, Majeed U, Aneaus S, Cánovas JAB, Stoffel M, Najar NA, Lotus S (2020) Impacts of erratic snowfall on apple orchards in Kashmir Valley, India. Sustainability 12 (21): 9206. https://doi. org/10.3390/su12219206

Rashid I, Parray AA, Romshoo SA (2019) Evaluating the performance of remotely sensed precipitation estimates against in-situ observations during the September 2014 mega-flood in the Kashmir Valley. Asia-Pacific Journal of Atmospheric Sciences 55: 209-219. https://doi.org/10.1007/s13143-018-0071-6

Rather ZA, Wachkoo AA, Khuroo AA, Dar AR (2019) First record of Aspicera hartigi (Hymenoptera, Figitidae) from India, with observations on its foraging behavior on Ephedra plants. Journal of Asia-Pacific Biodiversity 12 (3): 473-476

Sharma M, Bhattacharjee B, Lakshminarasimhan P (2012) Symphyotrichum subulatum (Asteraceae) - a first report of an alien weed in India. Nelumbo 54: 252-254.

Thapa S, Chitale V, Rijal SJ, Bisht N, Shrestha BB (2018) Understanding the dynamics in distribution of invasive alien plant species under predicted climate change in Western Himalaya. PLoS ONE 13 (4): e0195752. https://doi.org/10.1371/journal.pone.0195752

Tripathi Ak, Sharma JK (2019) Occurrence of Symphyotrichum squamatum (Spreng.) G.L.Nesom in Uttar Pradesh, India: a new record. Modern Phytomorphology 13: 26-29.

Tunckol B, Aksoy N, Yasayacak H (2017) A new record for alien flora of Turkey: Symphyotrichum pilosum (Willd.) GL Nesom var. pilosum. Modern Phytomorphology 11: 105-109. https://doi. org/10.5281/zenodo.1041920

Zachos FE, Mittermeier RA, Habel JC (2011) Biodiversity hotspots: concluding remarks and perspectives. In: Zachos FE, Habel JC (Eds.) Biodiversity hotspots: distribution and protection of conservation priority areas. Springer-Verlag, Berlin, Germany, 529-536 pp. 